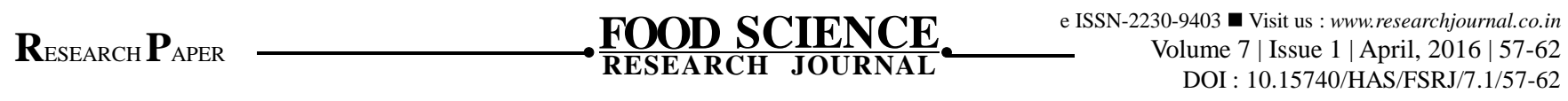

\title{
Utilization of sweetwater fish Catla Catla for preparation of plain and spiced fish sauce
}

\author{
R.R. Andhale, A.C. Dagadkhair and H.M. Syed
}

\begin{abstract}
The present investigation was undertaken with an objective to utilize the fresh water fish catla catla for the preparation of plain and spiced fish sauce. Fish sauce is an ingredient that has been used widely in Southeast Asian and also worldwide for the cooking purpose due to its specific flavour. The addition of spices to the plain fish sauce has showed the little change in sensorial quality of fish sauce. The different physico-chemical, sensorial and microbial parameters were determined. The different chemical results of plain sauce showed that it contains moisture, fat, protein , and ash was $68.40 \mathrm{~g}, 2.10 \mathrm{~g}, 7.3 \mathrm{~g}$ and $9.01 \mathrm{~g} / 100$, respectively. The $\mathrm{pH}$ of prepared fish sauce was 5.87. Total soluble solid content and total solids content of plain fish sauce was $30^{\circ} \mathrm{Bx}$ and 31.50 per cent, respectively. The viscosity was $17.40 \mathrm{cP}$. The results indicate that it is good source of protein and minerals. The spiced sauce with the formulation $\mathrm{T}_{2}$ got the highest score for the overall acceptability (8.5). The microbiological examination of plain fish sauce showed that the TPC of plain fish sauce was $5.6 \times 10^{5} \mathrm{cfu} / \mathrm{ml}$, the yeast and mold count was $1.2 \times 10^{2} \mathrm{cfu} / \mathrm{ml}$. T. Ultimately it reveals that it's a good source of probiotics i.e. Lactic acid bacteria.
\end{abstract}

Key Words : Fish, Sauce, Plain, Spiced, Microbial

How to cite this article : Andhale, R.R., Dagadkhair, A.C. and Syed, H.M. (2016). Utilization of sweetwater fish Catla Catla for preparation of plain and spiced fish sauce. Food Sci. Res. J., 7(1): 57-62.

Email : raj.andhale1@gmail.com

Associate Authors' :

A.C. DAGADKHAIR AND H.M. SYED, Department of Food Chemistry and Nutrition, College of Food Technology, Vasanthrao Naik Marathwada Krishi Vidyapeeth, PARBHANI (M.S.) INDIA 